\title{
WARUNG KOPI, MASYARAKAT VIRTUAL, DAN HIPEREALITAS (KETIKA WARUNG KOPI MENGABURKAN BATASAN REALITA)
}

\author{
Putri Maulina \\ Ilmu Komunikasi, Fakultas Ilmu Sosial dan Ilmu Politik \\ Universitas Teuku Umar \\ Email: putrimaulina@utu.ac.ic
}

\begin{abstract}
The phenomenon of coffee shops that have been prevalent in Aceh go hand in hand with the development of communication and information technology. The existence of a coffee shop that used to describe the miniaturized social interaction of the people of Aceh in a conventional way, now shifts its meaning as a means of reflecting the modernity of contemporary Acehnese society. The purpose of this study is to see how the shift in the meaning of the reality of coffee shops to contemporary Acehnese society. The theoretical and conceptual approaches used to examine the problems are: the Hiperealitas concept by Jean Baudrillard, and The Online Disinhibition Effect Theory by John Suler. This study is qualitative descriptive, using literature review method as data collection and analysis technique. The results of the study illustrate that: (1) the reality in the coffee shop is one part of the sign hypereality in the contemporary sociocultural context of Acehnese society (2) the disinhibtion behavior of the Acehnese community in cyberspace can also be formed from the intensity of activity in the coffee shop with free internet facility, and (3) the Acehnese community is a consumer society with 'ecstasy' of virtual simulations obtained from coffee shops.
\end{abstract}

\section{Keywords : Hyper-reality, Virtual Community, Consumerisme, Consumer Society}

\section{PENDAHULUAN}

Tradisi duduk di warung kopi memang sudah sejak lama dikenal oleh masyarakat Aceh dan mampu bertahan hingga saat ini. Warung kopi di Aceh hadir dalam bentuk yang beragam dan dapat ditemukan hampir di sepanjang jalan. Bagi masyarakat Aceh, warung kopi menjadi media komunikasi untuk berdiskusi dan bersilaturahim dengan sesama rekannya.

Warung kopi menjadi pusat berkumpulnya komunitas-komunitas untuk melakukan berbagai aktivitas sosial, sehingga tidak heran jika di warung kopi kita menemukan banyak pengunjung dari berbagai latar pekerjaan. Warung kopi di Aceh menjadi salah satu miniatur kehidupan sosial masyarakat Aceh, sehingga dari sini dapat dilihat bagaimana perkembangan realitas sosial masyarakat Aceh.

Perkembangan warung kopi di Aceh beriringan dengan bagaimana masyarakatnya berkembang. Sehingga membentuk tradisi yang memiliki esensi berbeda dari masa ke masa sesuai dengan perkembangan zaman dan arus globalisasi yang sedang berjalan secara menyeluruh di tengah-tengah masyarakat Aceh dewasa ini.

Teknologi komunikasi dan informasi yang berkembang dengan sangat pesat beberapa dekade terakhir turut mengubah gaya hidup masyarakat Aceh. Salah satu teknologi yang berkembang adalah internet. Media internet mampu berkembang dengan sangat masif dan menarik minat masyarakat Aceh kontemporer melalui keragaman fitur yang ditawarkannya. 
Perkembangan teknologi internet secara massif dapat dilihat dari grafik peningkatan penggunaan internet oleh kalangan masyarakat Indonesia, dan diperkuat dengan adanya datadata dari beberapa lembaga survey yang berwenang. Salah satunya adalah Asosiasi Penyelenggara Jasa Internet Indonesia (APJII), yang memaparkan bahwa pada tahun 2012, kurang lebih 63 juta masyarakat Indonesia terhubung dengan internet dan sebanyak 95 persen aktivitas yang mereka lakukan adalah adalah membuka media sosial.

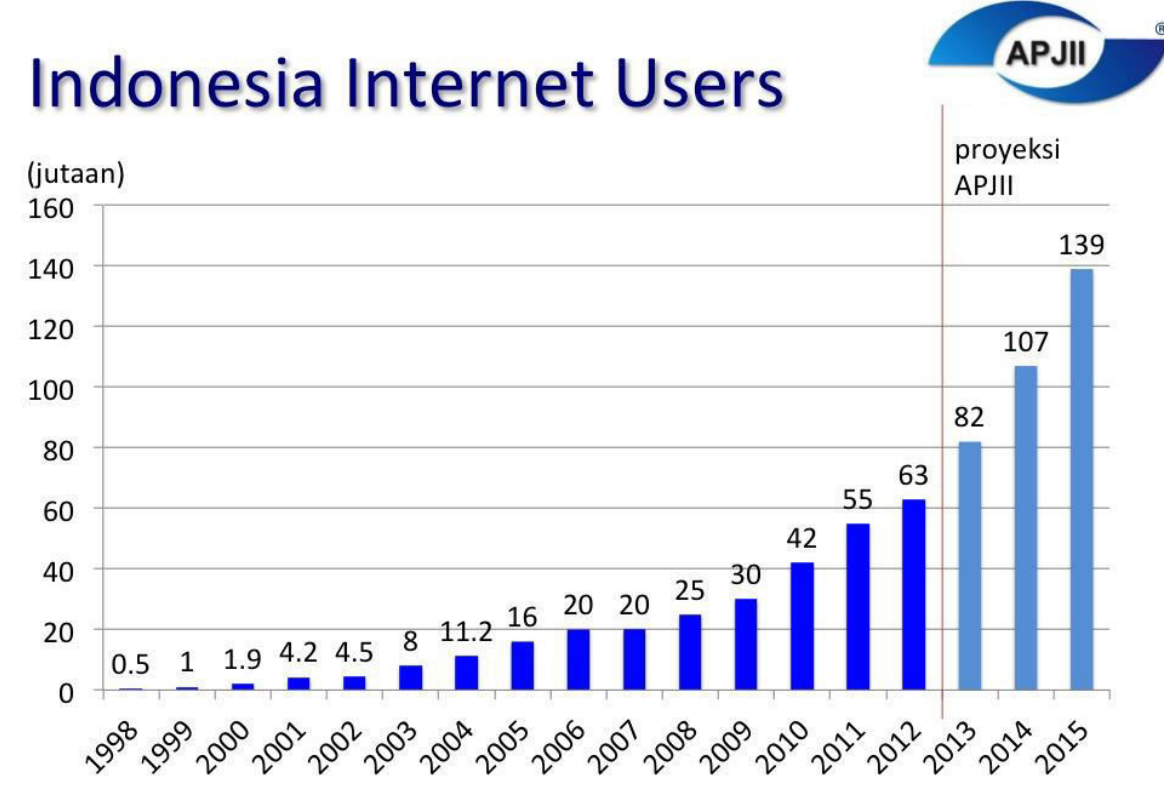

Sumber: https://apjii.or.id/

Berdasarkan data-data tersebut, dapat tergambarkan secara jelas bahwasanya masyarakat Indonesia semakin hari semakin aktif dalam menggunakan internet, dengan tingkat penetrasi yang mencapai puluhan juta orang. Semakin tingginya peningkatan penggunaan internet di tengah-tengah kalangan masyarakat dapat memungkinkan penyebaran konten ataupun informasi secara lebih mudah. Bahkan sampai informasi terkecil pun dapat menjadi perbincangan secara cepat oleh masyarakat di dunia maya.

Oleh karena itu, dampak dari mewabahnya internet sebagai media baru adalah kemudahan untuk mengakses informasi dan kemudahan untuk memberikan pengaruh negatif bagi penggunanya. Dennis Mcquail, menjelaskan bahwa ciri-ciri media baru adalah 1.) interkonektivitas, yaitu adanya akses terhadap khalayak individu, dan 2.) interaktivitas, yaitu kegunaan beragam untuk berbagai macam jenis manusia. Interkonektivitas berarti adanya hubungan antara satu perangkat dengan perangkat yang lain, sementara interaktivitas berarti di dalam media baru memiliki peluang untuk melakukan interaksi antara pengguna dengan pengguna yang lain. Ciri-ciri ini kemudian juga memungkinkan untuk memperluas peluang penyebaran informasi bohong atau hoax di tengah-tengah para pengguna media internet di Aceh secara khusus, dan di Indonesia secara umum. Juga memperkuat kasus bullying, cybercrime, atau penistaan bernuansa SARA.

Padahal, kasus-kasus penyalahgunaan media internet oleh masyarakat telah dibatasi di dalam Undang-Undang No. 11 Tahun 2008 Tentang Informasi dan Transaksi Elektronik (UU ITE). Yang mana undang-undang tersebut mendorong masyarakat untuk terhindar dari penyalahgunaan internet, yang berimplikasi pada keberlangsungan berbangsa dan bernegara.

Warung kopi saat ini menjadi salah satu tempat yang juga mempopulerkan aktivitas dunia virtual ini bagi masyarakat Aceh. Sejalan dengan perkembangan zaman kini banyak 
warung kopi di Aceh yang menyediakan fasilitas internet gratis dan meninggalkan konsep warung kopi konvensional yang hanya menyajikan kopi sebagai menu utamanya, sesuai dengan tujuan dari namanya warung kopi.

Kini, fasilitas internet gratis menjadi hal yang paling dicari oleh masyarakat Aceh ketika duduk di warung kopi selain dari meminum kopi itu sendiri. Warung kopi kini membentuk realitas sosial yang baru, tidak hanya untuk tempat minum kopi, silaturahim dan komunikasi tatap muka. Namun justru menawarkan sesuatu yang lebih dari itu, yaitu sebagai tempat untuk aktivitas berselancar di dunia maya. Realitas sosial yang terbangun di Aceh khususnya dan di Indonesia secara umum, menggambarkan suatu fenomena bahwa kebanyakan masyarakat sudah menganggap warung kopi sebagai tempat paling strategis dan menarik untuk berselancar di dunia maya.

Fenomena warung kopi di Aceh saat ini menawarkan banyak hal untuk diamati, khususnya bagaimana pergeseran realita sosial masyarakat Aceh yang berkembang di dalamnya, dampak dari kemudahan akses teknologi internet yang ditemukan oleh masyarakat Aceh kontemporer di warung kopi, dan bentuk-bentuk gaya konsumerisme masyarakat Aceh sebagai bagian dari ekspresi diri dan eksistensi masyarakat ketika berada di warung kopi.

Sehingga dari sini menarik untuk dikaji secara lebih jauh bagaimana pergeseran realita sosial mengenai gaya hidup masyarakat Aceh yang terjadi di warung kopi tersebut, beserta dengan dampak lain dari realita warung kopi yang mungkin terjadi di tengah-tengah masyarakat Aceh.

\section{KAJIAN PUSTAKA}

Di dalam kajian ini peneliti menggunakan beberapa teori yang dianggap relevan untuk mengkaji permasalahan yang diambil dari berbagai literature, seperti penekanan pada konsep Hiperealitas mengenai Cultural Studies, Teori The Online Disinhibition Effect sebagai pendekatan psikologi komunikasi, dan Komunikasi Virtual.

\section{Hiperealitas (Hyper-Reality)}

Dalam konteks pergeseran citra, makna, dan tanda terhadap suatu realitas, Jean Baudrillard memperkenalkan dua konsep penting yaitu "simulasi" (simulation) dan "hiperealitas " (hyper-reality) makna. Simulasi adalah proses penciptaan bentuk nyata melalui model-model yang tidak ada asal-usul atau referensi realitasnya, sehingga mendorong manusia untuk menciptakan dunia ilusi, fantasi, khayali menjadi terlihat nyata (Amir Pilliang, 2003: 21).

Ada empat tahap dalam simulasi yang dijelaskan oleh Baudrillard (dalam Amir Piliang, 2003: 134):

1. Ketika suatu tanda dijadikan refleksi dari suatu realitas.

2. Ketika suatu tanda sudah menutupi dan menyesatkan realitas itu sendiri.

3. Ketika suatu tanda menutupi ketiadaan dari suatu realitas.

4. Sehingga akhirnya suatu tanda sama sekali tidak berhubungan dengan realitas apapun, sebagai suatu simulakrum yang murni.

Sedangkan Hiperealitas adalah suatu keadaan di mana kepalsuan bersatu dengan keaslian, tercampur-baur. Masa lalu berbaur dengan masa kini, fakta bersimpang siur dengan rekayasa, tanda melebur dengan realitas, dusta bersenyawa dengan kebenaran. Hiperealitas menjelaskan kondisi budaya konsumerisme, masyarakat yang menjalankan logika sosial konsumsi, dimana kegunaan dan pelayanan bukanlah motif terakhir tindakan konsumsi (Baudrillard, 1970: 47). Dalam dunia yang hiperealitas manusia diberikan gambaran-gambaran yang penuh akan simbol, seperti benda, kegiatan, kota atau bahkan manusia. Simbol-simbol ini 
dipisahkan dengan realitas atau kenyataan yang sebenarnya terjadi dan hal tersebut menimbulkan tumbuhnya interpretasi yang menarik.

Hiperealitas adalah makna untuk mempersifatkan bagaimana kesadaran mendefinisikan "kenyataan" sejati di dunia, di mana keanekaragaman media dapat secara mengakar, membentuk dan menyaring kejadian atau pengalaman sesungguhnya. Hyperreality adalah ketidakmampuan kesadaran manusia membedakan kenyataan dan fantasi, khususnya dalam kehidupan berteknologi tinggi. Definisi singkat lain tentang hiperealitas adalah 'Nyata tanpa kenyataan (Jean Baudrillard)', 'Palsu yang otentik (Umberto Eco)', dan 'Ketidaknyataan virtual (Pater Sparrow)'.

Simulasi adalah proses atau strategi intelektual, sedangkan hiperealitas adalah efek, keadaan, atau pengalaman kebendaan atau ruang yang diproses tersebut. Baudrillard beranggapan bahwa hiperealitas mempertentangkan simulasi dan representasi. Simulasi bagi Baudrillard adalah simulakrum dalam pengertian khusus, yang disebutnya simulakrum sejati, dalam pengertian bahwa sesuatu tidak menduplikasi sesuatu yang lain sebagai model rujukannya, akan tetapi menduplikasi dirinya sendiri (Amir pilliang, 2004: 54-56).

\section{Teori The Online Disinhibition Effect}

Secara ringkas Online Disinhibition Effect menggambarkan suatu bentuk kehilangan dari pembatasan atau kekangan sosial yang secara normal ditampilkan dalam bentuk komunikasi tatap muka (face to face communication) yang kemudian beralih ke dalam bentuk komunikasi di dunia maya (virtual communication). Online Disinhibition Effect atau dikenal dengan ketidakmampuan menahan dorongan di dunia maya, adalah suatu kondisi psikologis di mana para pengguna dunia maya memiliki sikap atau perilaku sulit untuk mengendalikan dirinya ketika beraktivitas di dunia maya (Suler, 2004). Terdapat enam faktor utama yang menyebabkan perilaku disinhibition di dunia maya yang dijabarkan oleh Suler, yaitu: dissociative anonimity, invisibility, asynchronocity, solipsistic introjection, dissociative imagination, dan minimization of status and authority. Di sini Suler beranggapan bahwa kondisi-kondisi yang ditawarkan di dunia maya ini sangat memungkinkan penggunanya untuk merasionalkan perilaku maya mereka sebagai perilaku 'yang tidak benar-benar sama sekali' (Suler. 2004: 322).

Perilaku disinhibisi di dunia maya ini merupakan salah satu kajian mengenai dampak dari media internet terhadap perilaku penggunanya ketika berinteraksi secara virtual, yang ranah pembahasannya adalah dari ranah kajian psikologi sosial masyarakat. Salah satu dampak yang paling mungkin terjadi dari perilaku disinhibisi di dunia maya ini adalah cyberbullyng (hujatan di dunia maya). Cyberbullyng ini merupakan suatu perilaku individu untuk membuat individu lainnya merasa malu, terintimidasi, atau buruk terhadap dirinya sendiri. Namun demikian, secara positif perilaku disinhibisi di dunia maya ini juga memungkinkan penggunanya yang pada dunia nyata memiliki sifat negatif, dapat menjadi positif ketika di dunia maya dengan mempertimbangkan beberapa karakteristik yang ditawarkan di dunia maya.

\section{Masyarakat Virtual}

Masyarakat adalah kelompok-kelompok orang yang menempati sebuah wilayah (territorial) tertentu, yang hidup secara relative lama, saling berkomunikasi, memiliki symbolsimbol dan aturan tertentu serta system hukum yang mengontrol tindakan anggota masyarakat, memiliki system stratifikasi, sadar sebagai bagian dari anggota masyarakat tersebut serta relative dapat menghidupi dirinya sendiri.

Sedangkan masyarakat virtual merupakan sebuah kehidupan masyarakat manusia yang tidak dapat secara langsung di indera melalui penginderaan manusia, namun dapat dirasakan dan disaksikan sebagai sebuah realitas. masyarakat maya menggunakan seluruh metode kehidupan masyarakat nyata sebagai model yang dikembangkan di dalam segi-segi kehidupan maya. Seperti membangun interaksi sosial dan kehidupan kelompok, membangun stratifikasi 
sosial, membangun kebudayaan, membangun pranata sosial, membangun kekuasaan, wewenang dan kepemimpinan membangun system kejahatan juga control sosial.

Masyarakat maya membangun dirinya dengan sepenuhnya mengandalkan interaksi sosial dan proses sosial dalam kehidupan kelompok (jaringan) intra dan antar sesama anggota masyarakat maya. Proses sosial dan interaksi sosial dalam masyarakat maya ada yang bersifat sementara dan ada dalam waktu yang relative lama dan menetap. Sifat dan iinteraksi sosial mereka ditentukan oleh kepentingan mereka dalam dunia maya.

Masyarakat maya dibangun melalui interaksi sosial sesame anggota masyarakat maya. Syarat-syarat interaksi sosial dalam masyarakat nyata harus memiliki social contact dan communication. Persyaratan ini juga menjadi substansi utama dalam kehidupan sosial mayarakat maya. Hubungan yang di bangun dalam jaringan-jaringan computer, frekuensi radio, antena atau modem sesungguhnya adalah hubungan-hubungan sosial yang dibangun oleh anggota masyarakat untuk saling berinteraksi sedangkan mesin-mesin itu hanyalah media yang mereka gunakan.

Budaya dalam masyarakat maya tercipta oleh tiga unsur yang sangat utama yaitu:

1. Kelompok yang senantiasa bekerja untuk menciptakan mesin-mesin canggih dan realistis.

2. Kelompok yang setiap saat menggunakan mesin-mesin itu untuk menciptakan karyakarya imajinasi yang menakjubkan dalam dunia hiper-realitas.

3. Masyarakat yang pada umumnya setiap hari menggunakan mesin-mesin dan karyakarya imajinasi itu sebagai bagian dari kehidupannya.

Kehadiran ruang sosial maya memberikan perspektif baru dalam memahami perkembangan teknologi media. Ruang sosial maya ini berguna untuk mengeksplorasi dan menyalurkan segala informasinya tanpa memperhatikan batasan-batasan ruang dunia nyata. Sebagai bentuk alegori dari kesiapan manusia menuju pemahamannya terhadap realitas kesadaran rasionalnya.

\section{METODE PENELITIAN}

Adapun yang menjadi desain penelitian ini adalah jenis kualitatif-deskriptif dengan paradigma kritis. Metode yang digunakan dengan pendekatan kajian literatur atau kepustakaan (library research). Sumber data penelitian ini berdasarkan riset kepustakaan, dengan mengandalkan sumber-sumber primer yang terkait dengan pokok-pokok masalah. Penelitian dengan kajian kepustakaan ini berupaya menganalisis fenomena berdasarkan telaah literatur, teori-teori, dan konsep-konsep yang peneliti anggap berkaitan dan menjawab permasalahan yang akan dikaji. Sehingga ditemukan hasil analisis yang tepat dan memadai untuk memaparkan fenomena tentang warung kopi di Aceh. Adapun yang menjadi batasan dalam kajian ini adalah terletak pada pergeseran makna realitas yang berkembang di warung kopi dan kondisi sosiopsikologis masyarakat Aceh sebagai masyarakat konsumer virtual.

\section{HASIL DAN PEMBAHASAN}

\section{Warung Kopi Sebagai Faktor Pendorong Terbentuknya Masyarakat Virtual Dalam Dunia Hiperealitas}

Pada era millennial seperti saat ini, perkembangan warung kopi pun turut mengalami peningkatan baik dari sisi konsep dan fasilitas. Salah satunya dengan penyediaan fasilitas 
teknologi komunikasi seperti wifi gratis. Hampir di setiap warung kopi di Aceh kini dapat ditemukan fasilitas wifi gratis agar dapat menarik perhatian pengunjung. Sehingga saat ini, sudah menjadi hal yang lazim jika ditemukan banyak pengunjung yang duduk santai di warung kopi bersama gawai yang dimilikinya hingga berjam-jam lamanya.

Hal ini menggambarkan bahwa warung kopi di Aceh saat ini turut serta memfasilitasi perubahan pola hidup masyarakat Aceh, beriringan dengan kebutuhan masyarakat akan kemajuan teknologi komunikasi. Jika dahulu warung kopi menjadi media komunikasi tatap muka (face to face communication), di era millennial saat ini warung kopi justru cenderung menjadi media yang membatasi ruang komunikasi tatap muka.

Pengunjung warung kopi saat ini cenderung memanfaatkan fasilitas wifi gratis di warung kopi untuk menikmati pola komunikasi di dunia maya (virtual communication) untuk bercengkerama dengan berbagai kalangan yang ada dalam di dunia maya melalui berbagai fasilitas jejaring sosial yang dimilikinya. Komunikasi tatap muka pada awalnya menjadi inti dari tradisi duduk warung kopi. Pengunjung di warung kopi menjadikan warung kopi sebagai media pemersatu untuk bercengkerama, bersilaturahim, dan berdiskusi secara langsung di tengahtengah padatnya aktivitas dan kesibukan masing-masing.

Saat ini, tradisi duduk warung kopi telah berubah nilai substansinya. Proses komunikasi tatap muka yang dulunya lebih ditekankan, kini beralih pada gaya komunikasi bermedia di dunia maya (virtual) dengan memanfaatkan gawai masing-masing. Komunikasi di dunia maya ini kemudian dianggap lebih nyata daripada proses komunikasi sesungguhnya. Terlihat dengan banyaknya pengunjung yang lebih senang meletakkan perhatiannya pada gawai yang dimilikinya. Sehingga ramah-tamah antara sesama rekan di meja menjadi hilang. Berdiskusi dengan rekan-rekan di dunia maya dianggap lebih nyata daripada rekan-rekan semejanya.

Maka benar seperti yang dikatakan oleh Jean Baudrillard dalam bukunya Simulacra and Simulacrum (1989) mengenai hiperealitas (hyper-reality) di dunia maya, bahwa kemajuan teknologi komunikasi dapat mengaburkan batasan antara mana yang "kenyataan" dan "kepalsuan". Duduk semeja bersama rekan-rekan di warung kopi itu nyata, sedangkan berselancar di dunia maya, berbicara dengan rekan di jejaring sosial, meng-update status, mengirim foto, atau membagikan informasi-informasi di dunia maya itu jelas tidak nyata alias semu.

Karena apapun yang ditampilkan di dunia maya itu adalah realita yang telah terdistorsi oleh simbol-simbol dan tanda-tanda, sehingga akan sulit membedakan mana yang asli dan mana yang palsu. Sehingga aktivitas di dunia maya ini justru dianggap lebih nyata daripada realita komunikasi sebenarnya. Semuanya menjadi bagian realitas yang dijalani oleh masyarakat millenial Aceh dewasa ini. Hiperealitas, dijelaskan oleh Baudrillard, hampir selalu lebih menyenangkan daripada realitas. Bahkan ia dianggap lebih nyata dibandingkan realitas. Apa yang direproduksi dalam dunia hiperealitas tidak saja realitas yang hilang, akan tetapi juga dunia tidak nyata, fantasi, mimpi, ilusi, halusinasi, atau science fiction.

Seperti yang dijelaskan oleh Baudrillard:

“...hiperealisme dibentuk dari bagian integral realitas yang dikodekan dan diabadikan, dan tanpa mengubah apa-apa darinya." (Baudrillard, 1983: 147)

Dunia hiperealitas dengan sangat mudah menjebak masyarakat kontemporer Aceh dan memanipulasi mereka dengan segala bentuknya. Hiperealitas membutakan masyarakat dengan mereproduksi berbagai macam realitas dengan berbagai cara. Tidak hanya membutakan, hiperealitas juga membuat masyarakat kehilangan rasionalitasnya dengan menjebak masyarakat pada dunia virtual.

Hiperealitas membawa masyarakat pada situasi punya banyak kenalan di media sosial, tapi tidak punya sahabat dekat di kehidupan nyata. Sering berkomunikasi dengan orang lain di 
luar daerah, tapi bahkan tidak mengenal tentangga sendiri. Makin punya banyak informasi, tapi makin jauh dari fakta. Makin terhubung, tapi makin minim tindakan. Sehari menghabiskan waktu dua sampai tiga jam di warung kopi untuk chatting di dunia maya, tapi semakin jarang berkomunikasi dengan orang di dunia nyatanya.

Kondisi hiperealitas ini menjebak masyarakat dalam pseudo-existence atau eksistensi semu pada aktivitas di dunia virtual. Internet sebagai bentuk dunia virtual kini telah mencapai kemajuan yang pesat dan menawarkan fitur yang berbeda-beda. Namun, kemajuan tersebut justru menambah rentetan keanehan yang muncul pada kehidupan masyarakat Aceh kontemporer.

\section{Kebiasaan Masyarakat Di Dunia Virtual Sebagai Faktor Munculnya Perilaku Disinhibition}

Fasilitas internet gratis di warung kopi memang sangat memungkinkan masyarakat Aceh terperangkap ke dalam dunia 'simulasi' semu ini. Masyarakat Aceh semakin cenderung senang berselancar di dunia maya, sehingga dorongan-dorongan untuk berperilaku online bisa sulit dikendalikan.

Seperti yang dijelaskan oleh Profesor John Suler (2015) seorang pakar psikologi mengenai The Online Disinhibition Effect, bahwa ada kecenderungan pada diri individu untuk sulit mengontrol dirinya ketika berperilaku di dunia maya. Ketika individu berada di dunia maya, maka sangat memungkinkan bagi individu tersebut untuk secara terus-menerus mengupdate status, chatting, browsing, sharing, bahkan bullying, dan perilaku lainnya yang tidak dapat dilakukan di dunia nyata.

Inilah yang dikatakan sebagai perilaku "disinhibition" (ketidakmampuan menahan rangsangan yang terbendung)", apalagi dunia maya menawarkan anonimitas dan otoritas yang lebih besar daripada realita kehidupan sebenarnya terhadap diri seseorang. Sehingga membuat mereka merasa lebih bebas dan leluasa melakukan apapun di dunia maya daripada di dunia nyata. Ditambah adanya komunikasi yang sifatnya tertunda (asynchronicity communication), sehingga seseorang tidak terlalu khawatir dengan apapun yang dikomunikasikannya setelah dia keluar dari aktivitas di dunia maya.

Aktivitas di dunia maya oleh Suler memungkinkan penggunanya untuk lebih bebas mengekspresikan dirinya karena adanya enam aspek ini: (1) dissociative anonimity (kamu tidak mengenal saya!) yaitu menawarkan anonimitas sehingga penggunanya merasa bebas berkomentar karena tidak mengenal pengguna lainnya.

"When people have the opportunity to separate their actions online from their inperson lifestyle and identity, they feel less vulnerable about self-disclosing and acting out. Whatever they say or do can't be directly linked to the rest of their lives. In a process of dissociation, they don't have to own their behavior by acknowledging it within the full context of an integrated onlineloffline identity (Suler, 2004: 322).

Berikutnya adalah (2) invisibility (kamu tidak dapat melihat saya!) yaitu membuat penggunanya merasa bahwa orang lain tidak dapat melihatnya, sehingga merasa bebas melakukan apapun; (3) asynchronocity (komunikasi tertunda) ketika penggunanya dapat keluar dari dunia maya, dan meninggalkan apapun yang telah dilakukannya dengan tombol log out tanpa mau tau apa yang terjadi setelahnya;

"Some people may even experience asynchronous communication as "running away" after posting a message that is personal, emotional, or hostile. It feels safe putting it "out there" where it can be left behind" (Suler, 2004: 323). 
Kemudian (4) solipsistic introjection (semua ada di dalam pikiran saya!), yang membuat penggunanya secara bebas menuangkan apapun yang ada di pikirannya tanpa berpikir panjang; (5) dissociative imagination (ini hanyalah permainan), yang beranggapan bahwa dunia maya hanya sebuah permainan sehingga hal apapun akan dianggap sebagai gurauan atau candaan belaka;

Dan terakhir (6) minimization of status and authority (aturanmu tidak boleh diterapkan di sini!), yang mengizinkan penggunanya bersikap semena-mena atau memiliki otoritas tinggi terhadap akun yang dimilikinya meskipun itu salah. Masyarakat yang terbiasa duduk di warung kopi untuk mencari dan menggunakan fasilitas internet gratis dan berselancar di dunia maya, sangat memungkinkan untuk diserang oleh perilaku disinhibisi virtual, khususnya bagi generasi muda. Alasan mengapa suatu isu dengan cepat berkembang di masyarakat Aceh, terbentuknya komunitas-komunitas virtual, aksi hujatan, hinaan, banjir komentar, hoax, dan penindasan di dunia maya dapat difaktori dari perilaku disinhibisi ini.

Nicolas Carr menyebut hal ini sebagai citra kamuflase. Dalam buku The Shallows: What the Internet Is Doing to Our Brains, Carr berpendapat bahwa kehidupan digital telah mendangkalkan cara berfikir manusia. Salah satu mengapa pikiran menjadi dangkal, adalah karena citra-citra kamuflase tersebut. Masyarakat terbiasa hidup dalam alam yang bukan realitas, tetapi hiperrealitas. Terlebih di media sosial, masyarakat bisa mencitrakan dirinya sesuka hati. Sehingga kebiasaan masarakat untuk tergantung pada dunia inilah yang mendorong masyarakat untuk beranggapan bahwa dunia virtual itu adalah yang sebenar-benarnya realitas dan mendorong munculnya perilaku disinhibition pada masyarakat.

Aktivitas di dunia maya sangat memungkinkan penggunanya untuk lebih cepat menggunakan tangannya daripada pikiran. Sehingga hal ini mendorong banyak hal yang dianggap tidak pantas berkembang pesat di dunia maya dan dengan mudahnya dipercaya oleh para generasi millennial, seperti informasi hoax, situs-situs porno, game online, dan lain-lain.

Kemudahan fasilitas internet yang ditemukan oleh masyarakat millenial di warung kopi untuk mengakses informasi dan berkomentar di dunia maya dapat menjadi indikasi salah satu faktor yang membuat masyarakat sulit mengendalikan dirinya, selain dari gawai-gawai yang dimilikinya. Itulah mengapa, muncul perbedaan gaya hidup antara masyarakat Aceh pada masa sebelum warung kopi mengenal adanya internet gratis dengan setelah populernya fasilitas internet ini.

Berbeda dengan masyarakat Aceh dulu dengan tanpa kemudahan akses internet gratis di warung-warung kopi, masyarakat Aceh tempo ini adalah masyarakat global yang mampu menyerap berbagai informasi dari mana pun melalui internet, sehingga berdampak pula pada perubahan gaya hidup mereka. Maka tidak aneh jika pada era kontemporer dengan kemudahan internet, perilaku moral masyarakat Aceh, gaya hidup, fashion, dan berbagai tindakan lainnya jauh berbeda dengan era sebelumnya. Dengan kemudahan mengakses internet, masyarakat Aceh semakin berubah menjadi kritis, bebas, cenderung sulit dikontrol, dan tanpa batas.

\section{Warung Kopi Sebagai Pencipta Dunia Simulasi Virtual dan Bentuk "Ekstasi" Konsumerisme Virtual Masyarakat Aceh}

Secara lebih jauh, dapat dikaji bahwasanya posisi masyarakat Aceh dan kebiasaan mereka memanfaatkan warung kopi sebagai media untuk berselancar di dunia maya, menggambarkan suatu bentuk konsumerisme masyarakat terhadap terpaan teknologi komunikasi yang ditawarkan di tengah-tengah mereka. Masyarakat konsumer (consumer society) adalah masyarakat yang menciptakan nilai-nilai yang berlimpah melalui barang konsumer, serta menjadikan konsumsi sebagai pusat aktivitas kehidupan (Amir Pililang, 2003: 19). 
Hiperealitas dan perilaku disinhibition ini pada dasarnya tidak dapat dipisahkan dari keberadaan teknologi dan modernitas yang ditawarkan di tengah-tengah masyarakat Aceh saat ini. Akhirnya masyarakat sendirilah yang harus mampu mengontrol dan mengniterpretasikan setiap simbol-simbol yang ada tersebut. Konsumerisme masyarakat Aceh terhadap fasilitasfasilitas internet gratis di berbagai warung kopi akan membentuk hiperealitas terhadap media virtual itu sendiri, maka bukan lagi salah media massa dalam mengonstruksi simbol-simbol agar menciptakan imajinasi-imajinasi tertentu kepada masyarakat.

Hiperealitas menghadirkan model-model kenyataan sebagai sebuah simulasi (tiruan yang mirip dengan aslinya). Simulasi itu menciptakan simulacrum (jamak: simulacra), didefinisikan sebagai image atau representation, yang aslinya tidak pernah ada sehingga mengaburkan batasan realita dan kepalsuan. Hiperealitas membuat orang akhirnya terjebak pada simulacra, dan bukan pada sesuatu yang nyata. Dalam konteks kajian ini, maka di sini warung kopi di era kontemporer saat ini menawarkan aktivitas dunia simulasi virtual bagi masyarakat Aceh yang menampilkan citra-citra, tanda-tanda, dan menciptakan imajinasi terhadap masyarakat. Dunia virtual yang tidak pernah dapat kita bayangkan bagaimana bentuknya.

Dalam bukunya Simulation Baudrillard memperkenal istilah simulasi untuk menerangkan hubungan-hubungan produksi, komunikasi, dan konsumsi dalam masyarakat kapitalis konsumer. Yang dicirikan oleh overproduksi, overkomunikasi, dan overkonsumsi. Konsep simulasi juga menunjuk kepada pengalaman ruang dan pengalaman totalitas hidup dalam dunia simulasi kapitalisme modern. Simulasi pada dasarnya tidak terlepas dari perkembangan modern masyarakat kapitalis di Aceh itu sendiri, yang pada akhirnya kemudian dikenal sebagai masyarakat posindustri atau masyarakat (massa) konsumer.

Overproduksi, ini terjadi ketika pihak pebisnis warung kopi memproduksi tanda-tanda secara terus menerus kepada masyarakat Aceh untuk dijual dan menarik perhatian masyarakat. Overkomunikasi terjadi ketika masyarakat Aceh terlarut di dalam bentuk komunikasi yang sudah bercampur baur antara realita dan komunikasi yang khayali, seperti ketika mereka berada di dunia maya. Sehingga pada akhirnya yang terjadi adalah overkonsumsi di dalam masyarakat Aceh, yaitu ketika masyarakat terjebak dalam level komsumtivitas tinggi terhadap warung kopi, fasilitas internet, dan komunikasi virtual yang dilakukannya. Masyarakat merasa kecanduan yang besar untuk mengkonsumsi internet di warung kopi, tanpa mengetahui atau mampu membedakan antara konsumsi karena kebutuhan atau hasrat belaka.

Selain dampak dari konsumsi media virtual yang melaju pesat, teknologi media hubungannya dengan konsumsi juga berperan dalam proses produksi budaya massa. Artinya ini lebih dekat pada sebuah industri budaya sebagaimana yang ditunjukkan oleh Adorno dan Horkheimer, bahwa budaya tidak lepas dari dari ekonomi politik dan produksi kebudayaan kapitalis: sebuah paradoks bagi proyek Pencerahan.

"The culture industry fuses the old and familiar into a new quality. In all its branches, the products which are tailored for consumption by masses, and which to a great extent determine the nature of that consumption, are manufactured more or less according to plan." (Adorno, (J M. Bernstein ed.), 1991: 98)

Di dalam era konsumerisme, masyarakat hidup dalam relasi subjek dan objek yang baru, yatitu relasi konsumerisme. Di dalam masyarakat konsumer, objek-objek konsumsi dipandang sebagai ekspresi diri atau eksternalisasi para konsumer, dan sekaligus sebagai internalisasi nilai-nilai sosial budaya yang terkandung di dalamnya. Fasilitas internet gratis yang diberikan di warung-warung kopi merupakan objek konsumsi masyarakat Aceh, dan proses 
konsumsi terhadap fasilitas yang ada inilah yang menjadi wujud ekspresi diri atau eksistensi masyarakat kontemporer Aceh terhadap perkembangan teknologi yang mereka hadapi.

Akan tetapi secara lebih jauh, wujud ekspresi diri dan kebebasan masyarakat Aceh melalui konsumsi teknologi ini oleh Baudrillard tidak hanya dipandang dari sisi relasi kekuasaan atau kontrol diri masyarakat sebagai subjek terhadap objek dalam tindakan konsumi tersebut. Menurutnya, kontrol masyarakat terhadap tindakan konsumsi ini adalah sesuatu yang sifatnya semu disebabkan oleh suatu perubahan radikal yang terjadi pada relasi konsumsi di dalam masyarakat konsumer itu sendiri.

Maka Baudrillard menerangkan bahwa:

“...kita tidak lagi mengontrol objek, akan tetapi dikontrol oleh objek-objek ini."

"...apapun mengalir melalui mereka (konsumer), apapun menarik mereka bagaikan magnit, akan tetapi mengalir melalui mereka tanpa meninggalkan bekas apa-apa." (Barthes, 1973)

Di dalam massa konsumer yang pasif, mereka hanya akan menyerap setiap informasi, tanda, pesan-pesan, norma-norma akan tetapi tidak pernah merefleksikannya, oleh karena tidak ada yang dapat direfleksikan, meraka hanya mengkonsumsi. Mereka tidak perlu merefleksikan tanda, pesan, makna, atau norma-norma, karena mereka sendiri terperangkap di dalam kondisi skizofrenia. Di mana terlalu banyak tanda, terlalu banyak pesan, terlalu banyak informasi, terlalu banyak gaya. Tanda, pesan, makna atau gaya-gaya yang diambil dari berbagai sumber ideologi, kebudayaan, masa lalu atau masa kini, yang semuanya tercabut dari nilai spiritual dan realitas sosialnya yang nyata (Amir Piliang, 2003: 135-136). Bagi kelompok masyarakat seperti ini, apa yang dicari dalam konsumsi bukan lagi makna-makna ideologis, melainkan kegairahan dan "ekstasi" pada objek, dan yang dicari dalam komunikasi bukanlah pesan-pesan dari informasi, melainkan kegairahan dalam berkomunikasi itu sendiri. Dalam bermain dengan tanda, citraan, dan medianya. Begitu pula dalam penggunaan teknologi internet, semata-mata untuk mencari kegairahan dari kecanggihan internet dan atau dari proses komunikasi di dalamnya.

Massa disuguhi nilai-nilai penampakan, yang bukan reproduksi nilai-nilai mitologis atau ideologi. Dalam konteks ini masyarakat Aceh adalah konsumer yang transparan, yang menyerap nilai-nilai keterpesonaan (fascination) terhadap perkembang teknologi internet yang dahsyat dan fasilitas internet yang menjamur di warung-warung kopi Aceh. Tanpa harus menyerap nilai-nilai transedental warung kopi yang memang sudah tercabut dari realitas sosial objek-objek tanda dalam masyarakat Aceh. Hal ini merupakan model persepsi yang mendahulukan keterpesonaan dan ekstasi akan penampakan, daripada nilai-nilai transedental, yang mendominasi realitas sosial dan budaya masyarakat konsumer di Aceh. Mengganti kedalaman spiritual masyarakat Aceh tentang konsepsi budaya warung kopi dengan kedangkalan citraan atau tanda di dalam dunia virtual yang ditawarkan melalui ketersediaan fasilitas teknologi internet menjadi suatu bentuk ritual/kebiasaan baru, kemudian mengambil alih fungsi nilai-nilai realitas sosial yang sebenarnya dalam proses interaksi sosial masyarakat Aceh.

Masyarakat konsumer Aceh menjadikan kebiasaan nongkrong di warung kopi, menikmati ketersediaan internet gratis, dan berselancar di dunia virtual selama berjam-jam lamanya sebagai suatu bentuk "ekstasi" atau candu terhadap tanda realitas bayangan, realitas yang dibangun dalam dunia virtual. Sehingga mampu mencabut bentuk-bentuk komunikasi nyata yang seharusnya ada di dunia sebenarnya. 
"(realitas) menjadi realitas pengganti realitas, pemujaan (fetish) objek yang hilang bukan lagi objek representasi, akan tetapi ekstase penyangkalan dan pemusnahan ritualnya sendiri." (Baudrillard: 1983: 12)

Para kapitalis mereproduksi realitas lewat fasilitas teknologi internet yang ditawarkannya di warung-warung kopi dan memanipulasi kebutuhan. Seakan-akan fasilitas internet adalah satu-satunya yang dicari oleh masyarakat Aceh kontemporer ketika ke warung kopi. Membuat masyarakat justru mendatangi warung kopi bukan lagi untuk membangun silaturahim dengan rekan-rekannya, tetapi memilih untuk menggunakan internet. Yang sebenarnya mereka terjebak dalam kepentingan kapitalis untuk strategi bisnis mereka melalui manipulasi-manipulasi tanda, dengan memanfaatkan konsumerisme masyarakat Aceh terhadap kebutuhan untuk berselancar di dunia maya. Masyarakat Aceh dalam konteks ini pun dianggap sebagai massa konsumer, sebagai objek dari reproduksi tanda-tanda dalam relasi kuasa dan bisnis warung kopi modern di Aceh.

Dunia hiperealitas merupakan dunia yang dipenuhi dengan reproduksi secara silih berganti oleh objek simulakrum, yaitu objek yang murni sebagai penampakan, yang tercabut dari realitas masa lalunya. Di dalam dunia seperti inilah masyarakat Aceh sebagai subjek digiring ke dalam pengalaman ruang yang hipereal, pengalaman silih bergantinya penampakan di dalam warung kopi sebagai ruang, membuat realitas interaksi sosial yang nyata di warung kopi berbaur dan melebur dengan fiksi, halusinasi, dan fantasi dalam bentuk interaksi di dalam dunia virtual, sehingga perbedaan di antara keduanya menjadi sulit ditemukan (Amir Pilliang, 2003: 136).

\section{SIMPULAN}

Pada akhirnya simpulan yang dapat diambil dari kajian ini adalah dalam melihat fenomena realitas yang terjadi pada warung kopi dan masyarakat Aceh kontemporer saat ini, tidak hanya terbatas pada kacamata modernitas belaka. Namun jauh dari itu, fenomena yang terjadi merupakan ciri-ciri posmodernitas yang juga menjangkiti masyarakat Aceh melalui suatu pergeseran makna dan simbol di miniatur sosial masyarakat yang bernama warung kopi. Warung kopi saat ini menjadi suatu konsep realita yang telah mengaburkan batasan-batasan realita dalam konteks sosial-budaya masyarakat Aceh. Dengan beralasankan perkembangan teknologi komunikasi dan informasi, warung kopi saat ini pun mampu menggambarkan bagaimana masyarakat hidup dalam konstelasi makna-makna dan hiperealitas makna yang bercampur-baur antara realita dan imajinasi.

Kondisi hiperealitas di warung kopi ini dan keterikatan masyarakat milenial Aceh terhadap penggunaan fasilitas internet secara sosio-psikologis dapat mendorong sikap disinhibisi terhadap media maya oleh masyarakat Aceh. Aktivitas di dunia maya yang difasilitasi dengan adanya wifi gratis di warung-warung kopi memberikan peluang bagi masyarakat untuk lebih terdorong berselancar di dunia maya dan menjadi dunia ini sebagai suatu magnit besar untuk hasrat berperilaku. Perilaku disinhibisi ini berpeluang mengubah kondisi sosial masyarakat untuk lebih bebas mengekspresikan diri dan bereksistensi secara virtual.

Hiperealitas membutakan masyarakat dengan mereproduksi berbagai macam realitas dengan berbagai cara. Tidak hanya membutakan, hiperealitas juga membuat masyarakat Aceh kehilangan rasionalitasnya dengan menjebak masyarakat pada dunia virtual khayali. Sehingga apa yang ditemukan pada warung kopi ini menggambarkan terhadap apa yang disebut sebagai masyarakat konsumer, yang sudah tidak lagi mampu merefleksikan tanda, pesan, makna, atau norma-norma. Sebagai objek dari reproduksi tanda-tanda dalam relasi kuasa dan bisnis warung kopi modern di Aceh. Di mana terlalu banyak tanda, terlalu banyak pesan, terlalu banyak informasi, terlalu banyak gaya. Mendahulukan keterpesonaan dan ekstasi akan penampakan, 
daripada nilai-nilai transedental, yang mendominasi realitas sosial dan budaya masyarakat konsumer di Aceh. Mengganti kedalaman spiritual masyarakat Aceh tentang konsepsi budaya warung kopi dengan kedangkalan citraan atau tanda di dalam dunia virtual yang ditawarkan melalui ketersediaan fasilitas teknologi internet menjadi suatu bentuk ritual atau kebiasaan baru.

\section{REFERENSI}

Suler, J. 2004. The Online Disinhibition Effect. Cyberpsychology \& Behaviour. Journal of CyberPsychology \& Behavior. Vol. 7. No. 3. ResearchGate. Mary Ann Liebert, Inc.

Adorno, Theodor. 1991. Culture industry reconsidered (from "The Culture Industry: Selected Essays on Mass Culture"). London: Routledge.

Barthes, Roland. 1976. Mythology. London: Paladin Book

Baudrillard, Jean. 1983. Simulations. Newyork: Semiotext(e).

1988. The Ecstasy of Communication. Newyork: Semiotext(e).

1983. In the Shadow of The Silent Majority. Newyork: Semiotext(e).

1987. Forget Baudrillard. Newyork: Semiotext(e).

Piliang, Yasraf Amir. 2004. Posrealitas: Realitas Kebudayaan dalam Era Posmetafisika. Yogyakarta. Jalasutra.

2003. Hipersemiotika: Tafsir Cultural Studies atas Matinya Tanda.

Yogyakarta: Jalasutra.

https://apjii.or.id/ (diakses Sabtu, 21 April 2018) 